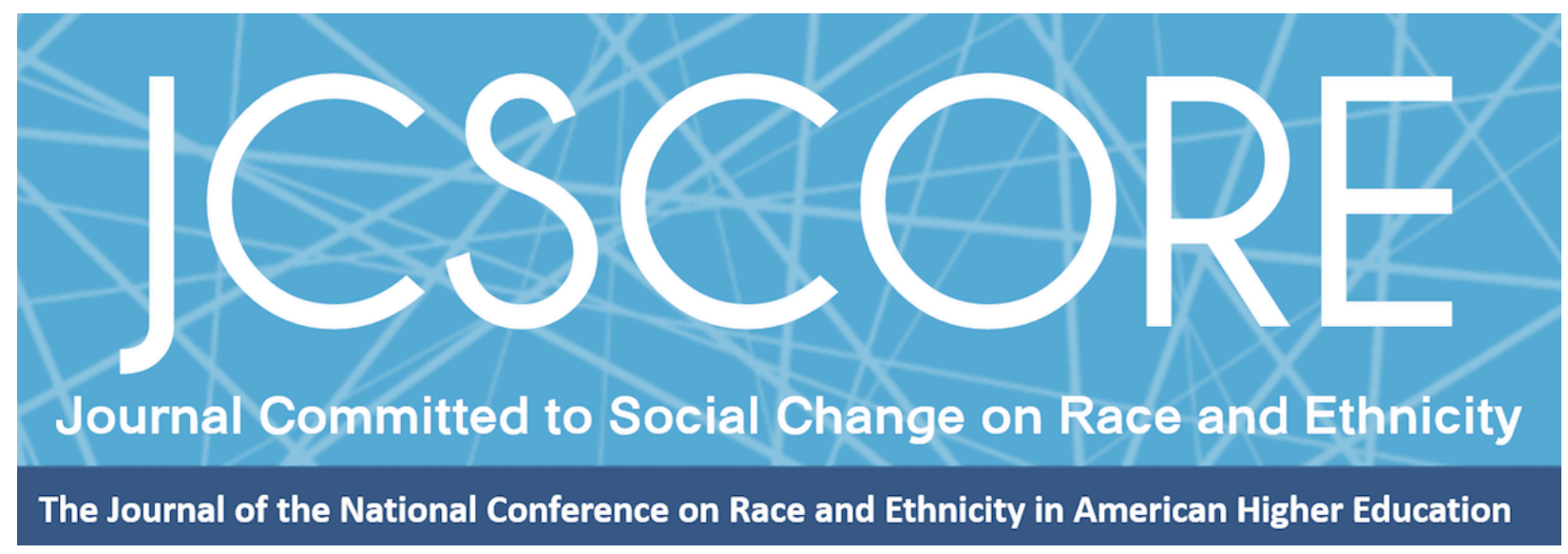

\title{
COMPLEXITY OF ACADEMIC SOCIALIZATION OF HISTORICALLY UNDERREPRESENTED DOCTORAL STUDENTS: DE-PRIVILEGING DISTINCTIONS BETWEEN MACRO- AND MICRO- THEORETICAL APPROACHES
}

\author{
Zarrina Talan Azizova \\ Oklahoma State University
}

Journal Committed to Social Change on Race and Ethnicity

Volume 2, Issue 2 | 2016

Copyright ( $\odot 2016$ Board of Regents of The University of Oklahoma on behalf of the Southwest Center for Human Relations Studies.

Permission of the Publisher is required for resale or distribution and for all derivative works, including compilations and translations. Quoting small sections of text is allowed as long as there is appropriate attribution. 


\title{
COMPLEXITY OF ACADEMIC SOCIALIZATION OF HISTORICALLY UNDERREPRESENTED DOCTORAL STUDENTS: DE-PRIVILEGING DISTINCTIONS BETWEEN MACRO- AND MICRO- THEORETICAL APPROACHES
}

\author{
Zarrina Talan Azizova \\ Oklahoma State University
}

\begin{abstract}
This article represents a conceptual work that critiques and challenges traditional linear theoretical assumptions of academic socialization and integration that are often applied to research of diverse populations in academia in general and doctoral education specifically. The article further proposes a new conceptual framework of academic socialization as a meaning-making act of historically underrepresented doctoral students. The ultimate goal of the proposed framework is to reconcile the restrictive use of sociological macro- and microorientations to foreground possibilities of a conceptual and empirical focus on an individual meaning making act (as a form of individual agency) of historically underrepresented doctoral students within the critical contexts of academia. The proposed framework offers methodological and analytical tools for a more complex qualitative research and institutional/individual practice to account for increasingly diverse populations in higher education.
\end{abstract}

Demographic shifts in doctoral education are profound as the enrollment of previously under-represented students has been growing (Bell, 2011; Hussar \& Bailey, 2011; Snyder \& Dillow, 2011). To embrace this change, scholars and practitioners in colleges and universities strive to develop new practices to accommodate diverse students and to launch more research on graduate education to inform institutional practices. Traditional academic socialization frames have been serving as one of the most popular lenses for institutional practice in graduate programs as well as for research about graduate students (Austin, 2002; Gardner, 2008, 2009; Gardner \& Barnes, 2007; Lovitts, 2005, 2008; Mendoza, 2007; Mendoza \& Gardner, 2010; Walker, Golde, Jones, Bueschel, \& Hutchings, 2008; Weidman, Twale, \& Stein, 2001; Weidman 
Journal Committed to Social Change on Race and Ethnicity | 2016

\& Stein, 2003). The main premise of these traditional socialization models rests on the imperative of students' integration and assimilation into an academic culture. However, navigating dominant cultural norms is particularly difficult for minority students (Davidson \& Foster-Johnson, 2001; Golde \& Dore, 2001; Nyguist et al, 1999; Walker et al., 2008). These models, therefore, become "deficit models" (Winkle-Wagner, Hinderliter Ortloff, \& Hunter, 2009, p. 3) because they are ill-equipped to inform practice and offer research measures or theoretical concepts to account for instances of students' differences and resistance or difficulties to fit and integrate into a new cultural environment (Lawrence, 2009; Rendon, Jalomo, \& Nora, 2000).

To understand a possible interplay between students' differences and academic socialization processes, McDaniels (2010) called for a departure from the modernist assumptions in theorizing socialization and, instead, to view it as "dialectical" and complex interactive processes (p. 30). Her view of socialization corresponds with Tierney's (2008) assertion that socialization should be understood as an interpretative, meaning making act of individuals.

This manuscript serves as an opportunity to accept the challenge of the above calls (McDaniels, 2010; Tierney, 2008) and to re-conceptualize traditional models to a new framework of academic socialization as an individual meaning-making act. To accomplish this task, I follow Mills' (1959) belief of interrelatedness of history, society, and individual biography, and exercise his sociological imagination to develop a symbiosis of more specific theoretical orientations into a new academic socialization framework. I hope to achieve a practical solution: To transform abstract theoretical ideas into a particular conceptual tool/theory that can have its utility in research and 
Journal Committed to Social Change on Race and Ethnicity | 2016

institutional as well as individual practice regarding historically underrepresented students.

\section{Literature Review}

Doctoral students, who are categorized as racial/ethnic minorities (Museus, Palmer, Davis, \& Maramba, 2011) and have been historically underrepresented in academia (Hurtado, Milem, Clayton-Pedersen, \& Allen, 1999), take their central positioning in this manuscript. Such students include students of color from African American and Latino backgrounds. Although doctoral enrollment is slightly growing for these two population groups (Bell, 2010), these students of color remain disproportionally underrepresented in doctoral programs and complete their doctoral program at much lower rates than their White and Asian counterparts (Hussar \& Bailey, 2011).

According to Mills' (1959) sociological imagination, understanding of individual experiences and subjective realities requires critical attention to social structures and historical conditions in which these experiences and realities emerge. Following this premise, I begin the survey of the existing literature about academic experiences of students. I, then, turn to reviewing the literature about traditional academic socialization models and practices to problematize the normalizing role of a social institution (such as universities/graduate programs). Finally, I provide a sketch of larger historical and national trends about higher education access and success of historically underrepresented students to stress critical dimensions of the broader context. 
Journal Committed to Social Change on Race and Ethnicity | 2016

\section{Individual Instances}

Navigating academia and getting socialized into the academic culture is not an easy task for students from historically underrepresented racial/ethnic groups (Golde \& Dore, 2001; Walker et al., 2008). Some scholars (Apple, 2009; Davidson \& FosterJohnson, 2001; Diangelo, 2006; Hollins, 2011) suggest that lack of racially/ethnically diverse faculty is a critical factor to consider in addressing troubled socialization experiences of racial/ethnic students. Doctoral students, such as African-Americans in Felder's (2010) study, state that diverse faculty was an important socialization factor to them. The demographic makeup of faculty in academia remains largely White (Snyder \& Dillow, 2011), while there is some increase of the racial/ethnic minority graduate students (Bell, 2010). Gay (2004) cautions that "the absence of a critical mass" of faculty from racial and ethnical backgrounds similar to graduate students of color "places psycho-emotional burdens" on these groups of students (p. 268). Other studies (Davidson \& Foster-Johnson, 2001; Oyserman \& Sakamoto, 1997) report contrasting experiences of graduate students of different racial and ethnic origins, compared to their White counterparts. While White students have more confidence in their interactions with professors, Latino/a students are traditionally from cultures that emphasize distance to authority and, therefore, are less comfortable in interactions with White faculty members (Davidson \& Foster-Johnson, 2001; Oyserman \& Sakamoto, 1997).

Such cultural differences in relations with faculty members may have certain implications on doctoral students' academic socialization as the role of faculty in socialization processes is profound. Felder (2010) observes that "socialization is influenced by the way classroom discussions are facilitated by faculty" (p. 467). 
Journal Committed to Social Change on Race and Ethnicity | 2016

Diangelo (2006) specifically documents critical instances when graduate level classroom dynamics reinforced White power and privilege, yet half of the students were students of color (some were of international origins). Diangelo (2006) shares her observations of the class that was run by a White male professor and a White female guest speaker,

The White students essentially controlled the class and tailored the learning that took place... Furthermore, they were affirmed as learners on multiple levels; their participation style was affirmed, their research interests were affirmed, their questions and comments were affirmed, and ultimately, their lack of any attempt to include the perspectives of the international students of color was affirmed. (p. 1993)

Johnson-Bailey, Valentine, Cervero, and Bowles (2009) compare Black graduate students, who graduated before 1986 to those who graduated after 1996, and find that both groups experienced discriminatory and racially hostile incidents at a Southern research university. Although discrimination by White professors was statistically lower for the graduates in 1996 compared to the graduates in 1986, the instances of discrimination still existed. In Gasman, Gerstl-Pepin, Aderson-Thompkins, Rasheed, and Hathaway's (2004) publication, two White female professors share how often they witnessed situations when their colleagues silenced, ignored, or misunderstood doctoral students of color. In the same publication, doctoral students of color reflect that there were times when they felt extremely frustrated and uncomfortable with faculty members. Cruz (1995) contemplates about her graduate experiences where her ethnicity was emphasized in her interactions with professors and peers inside and outside classrooms.

Gay (2004) conceptualizes such experiences into three categories: "physical, cultural, and intellectual isolation"; "benign neglect"; and, "problematic popularity" ( $p$. 
Journal Committed to Social Change on Race and Ethnicity | 2016

267). She discusses each of the categories as a form of marginalization that racial/ethnic doctoral students experience in their departments. Instances of being alone in their classrooms, being cut from intellectual conversations, and getting limited access to valuable information or knowledge are some of the conditions associated with the isolation. Lack of academic rigor, critical feedback, and helpful instruction from faculty members to help minority students develop their full academic potential sent implicit messages that the professors did not expect a high-quality performance from the students who participated in her study (Gay, 2004). The experiences of such marginalization are potent to discourage students from continuing their doctoral studies (Lovitts, 2001; Lovitts \& Nelson, 2000). One of the doctoral students in Gasman et al.'s (2004) publication shares her thoughts on getting close to dropping her studies, "something has got to give - it has to be me or the program" (p. 697).

Emphasizing the significance of student perceptions of a departmental culture in doctoral student attrition, the Division of Science Resources Studies of the National Science Foundation (1998) cautions:

Unlike the case of undergraduate education, the graduate education experience is shaped by specific situations - the student's relationships with specific faculty, in some cases just one or two members of a department. Research designs, therefore, ideally should capture that complexity. (p. 4)

Furthermore, NSF (1998) calls specifically for "contextual or qualitative data" to analyze doctoral students' experiences (p. 3). Whether and to what extent faculty members understand critical instances and address those in their interactions with students becomes a particularly critical question (Antony \& Taylor, 2009).

Learning rules and norms are important aspects of doctoral socialization (Gardner, 2008); however, forceful requirements of adopting may create difficult 
Journal Committed to Social Change on Race and Ethnicity | 2016

situations. Nyquist, Manning, Wulff et al. (1999) suggest that difficulties in academic socialization among some doctoral students can be attributed to value clashes and struggle to integrate into an academic value system and to meet academic expectations "expressed by various voices of authority" in academia (p. 20). Extending this argument specifically to racial/ethnic students' socialization experiences, Davidson and FosterJohnson (2001) assert that the issue becomes more profound as it stems from "the focus of graduate school preparation on assimilation of students of color into the dominant culture" (p. 554). According to other research findings (Beoku-Betts, 2004; Gildersleeve, Croom, \& Vasquez, 2011; Patton, 2009; Sallee, 2011), the hierarchical nature of relationships between faculty mentors and students are not always successful academically and socially as students of color perceive racism or gender bias, which "may be unintentional and a byproduct of dispassionate rules and actions intended to address the normed majority" (Johnson-Bailey et al, 2009, p. 198). In Gonzales' (2006) phenomenological study, Latina students are resistant to academic socialization because their ethnic identities are in strong opposition to the idea that "all students fit the same mold" (p. 359). Other reported instances suggest that students of color feel that they are "forced to adjust their behavior and natural forms of expression" (Gildersleeve et al., 2011, p. 104), which contributes to the problem of unjust "assimilation and homogeneity" (Gopaul, 2011). However, as Gonzales et al. (2002) state, some graduate students could address the issues of forced assimilation and view their departmental cultures "not something to accept and internalize, but rather something to challenge and negotiate" and become "change members" (p. 554). This view acknowledges an individual act or agency within the doctoral socialization 
Journal Committed to Social Change on Race and Ethnicity | 2016

framework. This acknowledgment echoes Tierney's (2008) call for departing the modernist understanding of socialization "as if it [were] a unitary and rational process embedded in an understandable culture" (p. 85) and conceptualizing socialization as an interactive meaning-making act. Thus, the interactive meaning-making act becomes a central focus of the proposed theoretical framework to address the crisis of student agency in academic socialization models and practices.

Overall, the review of the literature about individual experiences, perceptions, and beliefs reveals that critical instances of marginalization take place in academia. To provide a more insightful view into such experiences, Harper (2012) calls for expanding one's vision from individual occurrences to contextual and structural arrangements that perpetuate racism in academia (p. 10). He defines racism as "individual actions (both intentional and unconscious) that engender marginalization and inflict varying degrees of harm on minoritized persons; and institutional norms that sustain White privilege and permit of ongoing subordination of minoritized persons" (p. 10). Stewart (2013) clarifies that term "racially minoritized" captures oppressive functions of specific social contexts in experiences of students of color (p. 184). Harper (2012) contends that researchers should look at structural and institutional racism as a "logical explanation" for campus experiences and perceptions of students of color (p. 17). Bensimon and Bishop (2012) further suggest that critical understanding of racial experiences should focus on "structural racism: the systematic but often invisible way in which routine practices, traditions, values, and structures perpetuate racial inequality in higher education" (p. 2). Each of these stances echoes Mills' (1959) conception that an adequate understanding of life of an individual requires an explicit reference to the social institutions "within 
Journal Committed to Social Change on Race and Ethnicity | 2016

which his [the individual] biography is enacted" (p. 161). Hence, reviewing structural arrangements behind traditional socialization practices becomes an additional focus in the examination of the literature.

\section{Academic Socialization: Normative Structures and Practices}

Doctoral student socialization to academic norms of graduate programs, disciplines, and academic professions is one of the lenses to look at student learning and development toward their Ph.D. degrees. Some socialization models suggest a linear model of several stages of doctoral training (Tinto, 1993), while others assume simultaneous phases of student development (Gardner, 2008, 2009; Weidman, Stein, \& Twale, 2001). The desired outcome of successful academic socialization is usually associated with doctoral students becoming integrated fully into the culture of their profession and discipline (Council of Graduate Schools, 2008a, 2008b; Gardner, 2009; Golde, 2005; Lovitts, 2001, 2005; Tinto, 1993; Weidman \& Stein, 2003). Common across all models is the assumption that socialization is likely to influence students' retention and completion, facilitate personal and professional development, and secure students' progress towards their role of an independent researcher (Council of Graduate Schools, 2008; Gardner \& Barnes, 2007; Gardner \& Holley, 2011; Golde, 2005; Lovitts, 2005, 2008; Tinto, 1993; Weidman \& Stein, 2003).

In her three-phase socialization model, Gardner (2008) emphasizes that integration may be the most crucial phase in students' academic development. Presumably, integration processes enable students' formation as scholars as they learn and adopt particular values, norms, behaviors, and attitudes desired for the acceptance to a given culture of their academic department/discipline (Austin, 2002; Gardner, 2008; 
Journal Committed to Social Change on Race and Ethnicity | 2016

Lovitts, 2008; Weidman \& Stein, 2003). Gardner (2008) asserts that departmental culture as a live setting and faculty as socialization agents play a significant role in a student's transition to a scholarly role. By manifesting cultural norms, values, and behaviors, faculty members foster students' integration (Lovitts, 2008). Faculty and their academic departments establish various practices to communicate rules and values. For example, beginning with orientations programs and introduction into a discipline/field courses and ending with qualifying examinations before letting students conduct their own research, academic programs aim to ensure students' smooth transition into their roles of independent researchers (Gardner, 2008; Weidman \& Stein, 2003). Austin (2002) finds that informal practices such as observing, listening, and interacting with faculty are also instrumental in doctoral students' integration to the cultures of their graduate schools and academic disciplines. Overall, academic socialization scholars describe academic socialization as a seamless process of students' necessary adoption of norms and values of a given culture.

Culture, as Tierney (2008) observes, has a functionalist role from the traditional socialization perspective, as "An organization's culture, then, teaches people how to behave, what to hope for, and what it means to succeed or fail" (p. 86). However, from a critical minoritized standpoint, a given culture assumes some form of power to brand and alter new organizational members, which warrants some critical consideration and discussion of academic socialization. If viewed through Foucault's (1977) concepts, the programmatic forms and entailed practices of socialization (i.e. participating in coursework, undertaking assistantships, or receiving formal assessment of performance) may illustrate "the tactics of power" (p. 23) to normalize an individual to 
Journal Committed to Social Change on Race and Ethnicity | 2016

desired standards, norms, and values of a given culture. For example, practices of normalizing can be seen through a pass/fail or other types of assessment during doctoral coursework. Such an assessment may become what Foucault would call "as assessment of normality and a technical prescription for a possible normalization" (pp. 20-21). The power of this socialization practice produces new forms of behavior of doctoral students, which are considered to be appropriate in a given cultural context of the academic discipline/department. Students become "aware of the behavioral, attitudinal, and cognitive expectations" held for their role as a doctoral student (Gardner, 2008 , p. 329). Referring to the stage of integration into a program, one of the participants of Gardner's study (2008) implies self-disciplinary and normalizing effects of the socialization practices, saying that "you just kind of learn...you're going to have to learn what to do and what not to do" (p. 340). Formal coursework and its assessment measure students' capabilities and students' progress toward their degrees; hence, "Accordingly, students work diligently to prove to themselves, their peers, and their professors that they are capable and worthy to be a part of the intellectual community" and learn how to act, speak, and relate to the prescribed parameters of academia (Gardner, 2008, p. 47).

While altering and branding, the normalizing power of these socialization practices can be repressive. Coursework assumes learning and intellectual development and supposedly aims to foster creativity and independence among students (Lovitts, 2005). However, ironically, the entire practice of normalization through formal readings lists, assessment techniques, plans of study, and alike stands at odds with students' intellectual development and expression of intellectual 
Journal Committed to Social Change on Race and Ethnicity | 2016

uniqueness and creativity. The programmatic forms have measurement standards to monitor students' progress and thus make students focus on their performance (rather than their intellectual growth and success) and comply with these standards to demonstrate their competencies.

The most critical repressive power, however, is evident in a struggle of historically underrepresented students in adopting rules and norms of a mainstream academic culture (Cruz, 1995; Felder, 2010; Gasman et al., 2004; Gildersleeve et al., 2011; Gonzales, 2006; Gonzales et al., 2002; Hall \& Burns, 2000; Hollins, 2011; Johnson-Bailey et al., 2009). Gildersleeve et al. (2011) use the term "force" when examining Black and Latina/o students' "adjustments" of "their behavior and natural forms of expression" to the norms and rules in their departments (p. 104). One of the participants in their study describes that she learned about the rules on how one should speak in class from another student. The rules appeared as a "protocol of don'ts" to her (p. 104). Thus, self-expression and communication become "[self-] regulative through embracing normative expectations" (Weidman et al., 2001, p. 13). A student's fear of being watched and conformity to the rules normalizes and traps complicity within the individual and creates a disciplined individual (Foucault, 1977), who lacks opportunities for expressing uniqueness and being creative. Overall, if viewed through the Foucault's (1977) concepts of power and discipline, academic socialization of doctoral students presents itself as a powerful web of social structures that function to produce and repress at the same time.

However, simply making social and institutional structures responsible for critical experiences is not enough, if to follow the premise of Mills' (1959) sociological 
Journal Committed to Social Change on Race and Ethnicity | 2016

imagination. Seeking a better understanding of marginalized and repressed experiences requires a step further to a more complex "level of the historical reality" ( $p$. 174). As Mills (1959) urges, the sociological imagination promises a deeper account for isolated problems of "human variety" (p. 128) because its investigation takes us to complex historical textures of individual experience of a given social structure.

\section{History and Large-Scale Trends}

Only about 60 years ago, American public education faced a historic moment when the Supreme Court ruled "separate but equal" practices in education were not constitutional in Brown v. Board of Education decision of 1954 (Bowen et al., 2005;

Olivas, 2006). Before 1954, being admitted to the mainstream institutions was a difficult struggle on the part of students of color. In the illustration, the number of Black students on campuses constituted only about $0.8 \%$ of the new cohort of students across 19 institutions that reported their data in the fall of 1951 (Bowen, Kurzwell, \& Tobin, 2005). In some cases, minority students had to seek the interference of the Supreme Court to get admitted to a higher education institution, as evident in the legal cases of Black students in Oklahoma, such as Sipuel v. Board of Regents (1948). In other instances, admitted students of color were blatantly treated as a second class through the institutional practices that, for example, allowed these students to sit only in the corner of their classrooms (McLaurin v. Oklahoma State Regents, 1950). History of structural inequality, normalization of inequality, and practices of forceful assimilation in education, however, runs deeper, calling higher education scholars and practitioners to deconstruct this critical context not just through the binary terms of racial inequities. While statistical data on history of enrollment of other racial/ethnic students are simply absent (due to 
Journal Committed to Social Change on Race and Ethnicity | 2016

the miniscule numbers), legal cases, such as Mendez v. Westminster (1947) to dispute the constitutionality of segregation of Mexican schools as well as records such as the Browning Rule of 1896 to deny American Indian parents' right to choose a school for their children (Noori, 2011, Lomawaima \& McCarty, 2006; Stone, 2011) or personal narratives of educational experiences in boarding schools (Lajimodiere, 2012) are the other vivid accounts of history of oppression in education.

Post-Brown years followed by active recruitment of historically underrepresented racial/ethnic minority students. With that movement, however, came other legal disputes and challenges since the universities' reliance on standard academic admission requirements and use of academic qualifiers as a sole admission criterion perpetuated inequality in higher education access for racial and ethnic minority groups (The United States v. Fordice, 1992). Consequently, a series of litigation in higher education made a profound impact on shaping new policies for college access (Brown v. Board of Education,1954; Fisher v. University of Texas,2011; Grutter v. Bollinger,2003; Hopwood v. State of Texas, 1996; McLaurin v. Oklahoma State Regents, 1950; Regents of the University of California v. Bakke, 1978; Sipuel v. Board of Regents, 1948; United States v. Fordice, 1992). Cases, like Grutter and Gratz, have been serving as a primary framework for supporting institutional race-conscious admission policies. However, these policies continue to enjoy ongoing scrutiny and public and legal disputes, as evident in the most recent case Fisher v. University of Texas (2011). The pro-policy arguments typically originate from a well-documented empirical evidence that finds positive direct and indirect impact of student diversity on educational benefits such as educational attainment, learning outcomes including 
Journal Committed to Social Change on Race and Ethnicity | 2016

openness to diversity, and career aspirations of all college students (AERA et al., 2015; Mayhew, Rockenbach, Bowman, Seifert, Wolniak, Pascarella, \& Terenzini, 2016). Less attention in the arguments goes to the necessity of building a critical mass of diverse students to assure access as well as positive educational experiences for historically underrepresented populations.

Turning away from race-based admission policies raises strong concern about access of historically underrepresented groups to higher education. For example, assessing 40 years of trends of freshman students, Pryor, Hurtado, Saenz, Santos, and Korn (2007) observed that African American/Black students were particularly negatively impacted by the shifts from race-conscious admission policies to race-neutral. In her regression analysis of the effects of affirmative bans on graduate enrollment, Garces (2012) found that the bans contributed to the decline of enrollment of students of color by $12.2 \%$ across graduate programs, which is critically "larger enough" to jeopardize "critical mass" of students of colors (p. 123).

Socio-economic challenges are evident through a steady historical trend of a profound "gap in [higher education] opportunity for minorities" (St. John, 2002, p. 1). Cultural capital (St. John, 2006a; St. John \& Musoba, 2011), poverty and shifts from federal grants to loans (Geiger, 2005, Hu \& St. John, 2001; St. John, Baker \& Velez, 1996), and inadequate academic preparedness (Hu \& St. John, 2001; St. John, 2002) are determining factors attributed to the issues of college access. Moreover, Harvey and Anderson (2005) and St. John and Musoba (2011) report that African-American, Latino/Latina, and Native American students are significantly underrepresented in fouryear institutions. 
Journal Committed to Social Change on Race and Ethnicity | 2016

Restricted access to four-year and selective institutions cannot be a value-free problem, especially within the discourse about a need for a diverse graduate education pipeline (Council of Graduate Schools, 2008b): "While there are institutions, namely community colleges, that facilitate open access for those who seek educational opportunities beyond high schools, selective public institutions award credentials to those entering professional fields - law, business, medicine, and academia - to gain entrance into a higher stratum of society" (O’Neil Green \& Trent, 2005, p. 108). Harper and Porter (2012) report specifically that racial differences in GRE scores between Black men and White men are drastic: 860 of mean total for Black men compared to 1125 for White men. More broadly, Patton (2013) summarizes recent GRE data from the Educational Testing Service and reports that Black and Hispanic test-takers produced the lowest scores in quantitative, verbal, and writing sections.

Overall, the overview of the history of higher education and other large-scale trends on minority groups reveals a difficult path to graduate education that continuously requires historically underrepresented students to overcome socioeconomic and cultural inequalities. Altogether, the literature review has provided ample evidence through the publications of others to enunciate critical orientations in individual experiences and contextual and structural conditions.

\section{Toward a Theoretical Framework}

Given a strong critical conviction gained through the literature review about doctoral experiences of historically underrepresented racial/ethnic students, I lean to the elements of critical theory in the re-conceptualization of academic socialization as a meaning-making act. As Frances Stage (2007) urges, I want to reinforce that my 
Journal Committed to Social Change on Race and Ethnicity | 2016

purpose is to achieve a transformational outcome in this project rather than to exercise a radical criticism of traditional academic socialization theoretical frameworks and practices. I continue following Mills' (1959) sociological imagination to weave distinct theoretical orientations to acknowledge a critical role of history and structural conditions and foreground an individual student's attempt at his/her meaning making. A transformative outcome entails a discovery of possibilities (in research and practice) of student agency in each socialization/meaning-making experience. I, therefore, propose the following conceptual framework of academic socialization as a meaning-making act for research and practice.

\section{Presuppositions}

Before I turn to the discussion of theoretical orientations and ways of bridging them into a single conceptual frame, I need to reiterate basic presuppositions of doctoral socialization. First, I emphasize the basic premise of the doctoral socialization, derived from the literature: According to the scholars (Austin, 2002; Gardner, 2008, 2009; Gardner \& Barnes, 2007; Golder \& Dore, 2001; Lovitts, 2008; Mendoza, 2007; Weidman, Twale, \& Stein, 2001), socialization is an essential and inevitable process in doctoral training. Being fully socialized to academic culture enables doctoral students with a greater academic success in their respected fields. Then, I follow McDaniels's (2010) call for studying socialization of doctoral students as dialectical and complex process and Tierney's (2008) call for a paradigm shift from an objectivist view to the postmodern perspective of socialization. His postmodern view implies that socialization is an interpretive act of socialized ones who create meanings and make sense of an 
Journal Committed to Social Change on Race and Ethnicity | 2016

organization through their unique backgrounds as well as through the contexts in which the organization operates.

The above-mentioned premises about socialization help me pull out four basic presuppositions, which inform my theoretical choices for the development of the frame:

1. socialization is an imperative process in doctoral training (individual-rational: goal-oriented);

2. socialization is a meaning-making process (individual-nonrational: the endeavor that involves interactions);

3. socialization is regulated by current contexts (collective-nonrational: takes places in cultures, value systems); and,

4. socialization is regulated by a pre-existing organizational system (collectiverational: takes places within certain structural arrangements and historical conditions).

While the last two presuppositions recognize the immanent social order (i.e. history, contexts, structures, organizations), the other two are concerned with the dimension of social action at the individual level. Social action, such as historically underrepresented doctoral students' meaning making through their interactions with faculty and institutions/departments is a unit of the analysis. The social order recognizes certain pre-established conditions in which individual's social interactions and meaning-making occur, which is an interpretive base of individual meanings. Next, I proceed to present general theoretical orientations that guide me in elaborating a new doctoral socialization theoretical frame of historically underrepresented racial/ethnic students.

\section{Theoretical Foundation}

Like Tierney and Rhoades (1993), I mix critical theory and postmodernism, but not in a manner they utilized. While Tierney and Rhoades subscribe to postmodernism to "know about" this world and utilize critical theory "to act in" it (p. 308), I subscribe to 
Journal Committed to Social Change on Race and Ethnicity | 2016

critical orientations (Foucault, 1977; Johnson, 2006) to "know about" the social order and refer to particular tenets of postmodernism (Holstein \& Gubrium, 1998) to suggest methodological and practical possibilities for foregrounding students' meaning making acts. I also add a third layer of yet another theoretical orientation to interpret how meanings of a socialized self are born through social interactions: I turn to the phenomenology of social interactions (Schutz, 1967/1932). Social interactions and meaning making of a new member of an organization do not begin from a zero point or occur in a vacuum. Rather, social interactions take place within certain pre-existing cultural, organizational, and historical conditions - which is the social order.

The nature of social order and social action in social life are the fundamental concerns and questions of sociologists (Appelrouth \& Edles, 2008; Alexander, 1987). Social order considers various social accounts that are responsible for the emergence of particular patterns of social life. Social order distinguishes collective and individual social realities that are placed on each end of a continuum (Figure 1). The collectivist orientation assumes that pre-existing structures and systems or historical conditions work down on individuals and groups (p. 13). In other words, individuals and groups follow certain social paths that essentially are not results of their actions (Appelrouth \& Edles, 2008). The individualist orientation treats the social order as a product of ongoing interactions and meaning-making processes of individuals. In other words, the individuals "work up" to produce society as they constantly involve in creating, recreating, and transforming social order. The question of social action considers various factors and forces that direct and guide an individual or group behavior in a particular order. The action is placed on the two ends of the other continuum, distinguishing 
Journal Committed to Social Change on Race and Ethnicity | 2016

between rational and non-rational nature of the action (Figure 1). A non-rational nature of the action is motivated by cultural complexities of values, norms, traditions, desires, or emotions. In contrast, a rational nature of the action is influenced by individuals' selfprompting interests, not values, to achieve their role they desire in the society (p. 13).

Usually, both sociological stances, the order, and the action, are methodologically divided into micro - (interpretative) or macro- (structural) approaches to let the researcher relate to either bottom-up or top-down orientations (Holstein \& Gubrium, 1998). However, in The new language of qualitative method, Gubrium and Holstein (1997) asserted that dialectical relationship "deprivileges the distinction between the two strategies", suggesting that "neither takes precedence over the other" but "like two sides of the coin, interpretative artfulness and substantive conditions mutually inform one another" (p. 212). Guibrim and Koro-Ljunberg (2005) further presented a particularly useful note that to follow the phenomenological premise that meanings are not created merely through subject to object, but born in interaction, researchers need to pay attention to "a particular historical and cultural context" ( $p$. 711).

Consequently, to "know about" (Tierney \& Rhoades, 2008) historical and cultural context, the social order, in which social interactions and meanings take place, I choose Johnson's theoretical concepts derived from the traditions of critical inquiry (i.e. Adorno, Horkheimer, Marcuse, Marx). Culture (in the form of ideas, thoughts, beliefs) and superstructure (in the shape of organization, systems, hierarchy) at the center of critical inquiry stress that individual meanings and critical thinking are limited and oppressed due to the certain structural arrangements. The power system can also be diffused and 
Journal Committed to Social Change on Race and Ethnicity | 2016

subtle, rather than organized and structured in a top-down manner. To Foucault (1977), social practices, norms, and normalizing mechanisms can be powerful forces of dominance over individuals' rational capacities and conscious decision-making. These critical ideas are complimentary to understanding a complex web of power resulting in oppression and repression of individuals' meaning-making possibilities. Stage (2007) supports a critical researcher or theorist in accepting this complex critical assumption, reminding that "oppression has many faces that must be examined simultaneously" ( $p$. 7).

Often, however, Foucault's concept of power and Johnson's power and privilege take a deterministic interpretation: a totalitarian influence on individuals' construction of self, from which there is no escape and "possibilities of self-creation are increasingly slim" (Miller, 2008, p. 257). Foucault (1977) identified diffused power in his investigation of panopticon that provides insights into a systematic socialization to rules and internalization of norms which result in a self-sanctioning behavior of these individuals. When a person follows prescribed norms and rules, believing that she or he is being monitored (even though there is no centralized power figure to monitor), this individual becomes a disciplined member of the given setting. This power, like culture, is a social web in which everyone is trapped (Crotty, 1998).

Miller (2008), however, revisited deterministic powers on individuals to stress human agency and offer new accounts for postmodern interpretations of, what she calls, Foucauldian constructionism. She further called for shifting the focus of research to "the ways actors take the dominant (but also marginalized) discourses and strategically rework them in specific social setting" (p. 259). This emphasis on the 
Journal Committed to Social Change on Race and Ethnicity | 2016

construction of self and meaning- making returns us to Schutz's (1967) social phenomenology and underlying concept behind individuals' social interactions. Together, the theoretical ideas of critical inquiry and phenomenology are connected through the assumption that the essence of individuals' reality lies in individual meanings that are mediated by power relations. This connectedness between thoughts and reality of experience implies a dialectic relationship in which both, social action and social order, inform each other (Gubrium \& Holstein, 1997; Holstein \& Gubrium, 1998). Gubrium and Holstein (1997) help specifically bridging structural realism and individual subjectivity by offering recognition of "substantive conditions" and "interpretive artfulness" as "two sides of the same coin... that can never be fully separated" (p. 212) and could be connected through a dialectical methodological approach. A possible transformation of student experiences through the emphasis on his/her phenomenological meaning-making lies in the recognition of such dialectics: whenever power is experienced or perceived, an individual resistance or response is always present.

Overall, interweaving these theoretical foundations and reconciling their epistemological differences captures the essence of Mills' sociological imagination: foregrounding an agentic role (meaning-making acts) of individuals within constraining structural and historical realities (Figure 1). Such theorizing becomes an analytical/research and practical device for transforming academic socialization conceptualizations and experiences. 
Journal Committed to Social Change on Race and Ethnicity | 2016

\section{Implications}

The redefined academic socialization theoretical frame renders conceptual options for integrating researcher's and practitioner's critical consciousness into the intersection of a subjectivity/meaning-making of individuals and historical, cultural, and structural conditions (Gubrium \& Holstein, 2001, 2003, 2009; Holstein \& Gubrium, 1995). Bridging micro- with macro-concepts may become a more complex and critical way of studying doctoral programs' practices and individual experiences within them. More to a transformational end, altering conventional theoretical models may offer possibilities of "questioning assumptive practices and generating possible alternatives" (Stage, 2007, p. 8) and accounting for students' differences rather than similarities in research and practice.

\section{Research}

As Lawrence (2009) justly pointed, educational research neglects individual experiences of minority groups. She called for research to be focused on "the margins" in order to "encounter constructs that have been overlooked or simply not recognized"; " encounter evidence that suggests [socialization in schools] is an epic process that perpetuates and adapts cultures"; "encounter groups who neither look nor act like those who are the White, Euro-American norm"; and, "[free] us from concentrating myopically on how the individual accumulates information, applies skills, and adopts normative positions in school" (p. 80). Thus, the empirical shift has to take place in the recognition of individuals and their meanings as human diversity grows, people variety changes, and predictions of one's experiences through fit-them-all models make no complete sense. Soliciting different meanings and generating idiographic and contextual data 
Journal Committed to Social Change on Race and Ethnicity | 2016

(Stage, 2007) may help to build up new mid-level theoretical models for a betterequipped research addressing diversity and differences in institutional practices of graduate programs.

At its current stage, research guided by the proposed theoretical framework warrants postmodern methodologies that focus on meaning-making acts and view "subjects who are reflexively working out who and what they are as they articulate and ramify the myriad self-narratives of contemporary life" (Holstein \& Gubrium's, 2000, p. 232). Encouraging such a constructionist methodological approach to data collection and data interpretation means soliciting participants' personal stories as meaningcarriers, and then placing these meanings into the larger historical, cultural, and structural conditions in which those personal (often critical) biographies emerged. This methodological approach will lead to a generation of new kinds of data on doctoral student experiences and translation these new data into new models of practice.

To pursue this critical, postmodern methodological act, Guba and Lincoln (1994) suggest that a dialogic process between a researcher and participants needs to be common "to transform ignorance and misapprehensions ([such as] accepting historically mediated structures as immutable) into more informed consciousness ([such as] seeing how the structures might be changed and comprehending the actions required to effect change)" (p. 110). In other words, the dialogic methodological processes assume some form of interaction between a researcher and a participant (Scheurich, 1995), in which a role of an individual participant as a meaning-making actor prevails over the substantive conditions (historical or contextual), yet personal meanings find interpretations within those conditions. An example of such research methods is present at Gubrium and 
Journal Committed to Social Change on Race and Ethnicity | 2016

Hosltein's (1995) active postmodern interview as this method attends to the process as well as the substance of interview: how responses get produced and what meanings and representations of reality emerge.

\section{Institutional Practice}

Doctoral programs that are increasingly accepting diverse students and still emphasizing the premise of cultural integration and assimilation may face students' departure or deal with students' frustrations more often than not. The proposed theoretical frame in this paper and its research methods are complex and thus capable of addressing structural limits of an individual meaning-making act. Attending to minority students' meanings (what) and ways they develop throughout the socialization experience (how) may inform practitioners about ways of "what can and what must be structurally changed if the role of individual meaning-making act is to be enlarged" (Mills, 1954, p.174). Thus, paying attention to individuals and their meanings as they participate in socialization practices of their program may inform deliberation of new policies and practices in doctoral programs that may depart from the concept of organizational culture as social and normative glue (Kuh \& Witt, 1988). Informed practices may instead stress that there should be more differences than similarities as distinguishing features in higher education (McDermott \& Varenne, 1995). I offer some examples of how to translate such transformative vision of the individual meaningmaking act into the program-level academic socialization practices. First, establishing student advisory groups to assist faculty in their work on design and revision of program curriculum may promise development of a more inclusive academic content as well as intercultural doctoral pedagogy in the program. Such practice also enlarges students' 
Journal Committed to Social Change on Race and Ethnicity | 2016

meanings in their learning and development as well as empowers students' sense of ownership of their success. Second, new student orientations should be revised every year based on the ongoing student evaluation loop. Soliciting feedback on program orientations from students in their second and third years of studies may help faculty know which program areas they overlook in the initial socialization stage. Third, program faculty may develop mid-program orientations for the students who have reached their mid-point in their doctoral degree program. In addition to brief sessions reminding students about degree progress and completion requirements, these programs may include (a) student-faculty sessions with the discussions about student social identities, paths to doctoral education, and career objectives, (b) student-student workshops about perceived barriers to degree competition and best strategies overcoming these barriers, and (c) student feedback. Fourth, program faculty should take a proactive approach to organizing, facilitating, and rewarding peer mentorship initiatives between first-year doctoral students and their advanced peers. Purposeful paring of doctoral students based on their career objectives, research interests, social experiences, and cultural background may be particularly helpful promising to enhance a student support base and sense of empowerment. Through such practices, students may realize that they are not products of their programs, but that they are active social members who produce and re-produce meanings of a doctoral student socialization.

Thereby, doctoral programs/departments may acknowledge and accept student differences and various individual interpretations and understand their organizational culture as "not much a product of sharing" but an ongoing process of construction and negotiation of social reality (McDermott \& Varenne, 1995, p. 326). Such a process, 
Journal Committed to Social Change on Race and Ethnicity | 2016

however, cannot be complete without an informed and conscious practice of individual students.

\section{Individual Practice}

Research, employing old objectivist socialization models to predict and explain experiences of "human variety" (Mills, 1954), creates "the crisis of individuality" and "the crisis of history-making" (p.174). Therefore, most importantly, the integral promise of this framework is addressed to a doctoral student in their everyday practice. The promise of a meaning-making act rests in the exercise of the sociological imagination and self-consciousness. It is the promise of escape from historical, cultural, and structural traps and of celebration of individual freedom to act, to reason, and to develop independent meanings of self (Mills, 1954). To assume an individual meaning-making act requires a caution though that structural conditions, formed and cemented throughout the long course of history, may limit an individual's decision to act and reason (Mills, 1954). However, as Mills promises, it is possible and crucial to realize that independent reasoning or individual meaning-making acts may have "structural consequences for social institutions and history, and thus for own life fates" (p. 174). Thus, connecting individual meanings with an institutional culture and society's history, the individual undertakes a social task of meaning-making act to articulate an active role of human agency and to develop choices in culture- and history-making of a diverse doctoral education. 
Journal Committed to Social Change on Race and Ethnicity | 2016

Figure 1. Doctoral Student Socialization as a Meaning-Making act

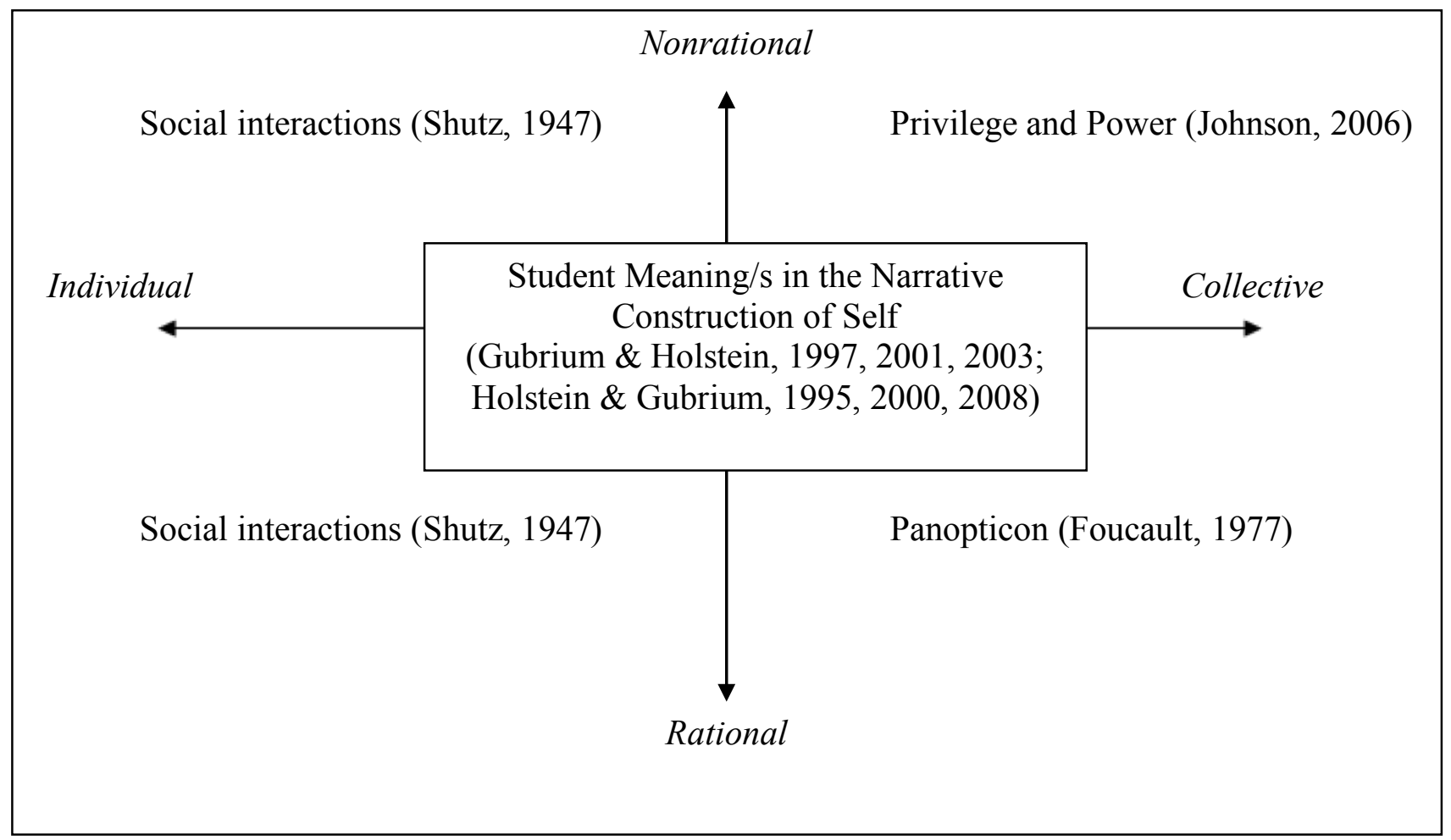

Adapted and modified from "Classical and contemporary sociological theory: Text and reading," by S. Appelrouth and L.D. Edles, 2008, pp. 15-16. Copyright 2008 by the Pine Forge Press. 
Journal Committed to Social Change on Race and Ethnicity | 2016

\section{References}

Antony, J. S. \& Taylor, E. (2001). Graduate student socialization and its implications for the recruitment of African American education faculty. In W. Tierney (Ed.) Faculty work in school of education (pp. 189 - 210). Albany, NY: State University of New York.

Apple, M. (2009). On the tasks of the critical educational scholar/activist. In R. WinkleWagner, C. Hunter, \& D. Ortloff (Eds.) Bridging the gap between theory and practice in educational research: Methods at margins (pp. 21 - 34). New York, NY: Palgrave Macmillan.

Austin, A. (2002). Preparing the next generation of faculty: Graduate school as socialization to academic career. The Journal of Higher Education, 73(1), 94 122.

Baker, T. \& Velez, W. (1996). Access to and opportunity in postsecondary education in the United States: A review. Sociology of Education, 69, $82-101$.

Barker, M. (2011). Racial context, currency and connections: Black doctoral student and white advisor perspectives on cross-race advising. Innovations in Education and Teaching International, 48(4), 387 - 400.

Bell, N. (2011). Graduate enrollment and degrees: 2000 to 2010. Washington, DC: Council of Graduate Schools and Graduate Record Examination Board

Bensimon, E. M., \& Bishop, R. (2012). Introduction: Why "critical"? The need for new ways of knowing. The Review of Higher Education, 36(1, supplement), 1 - 8.

Beoku-Betts, J. (2004). African women pursuing graduate studies in the sciences: Racism, gender bias, and third world marginality. Feminist Formations, 16(1), $116-135$.

Bowen, W., Kurzwell, M., \& Tobin, E. (2005). Equity and excellence in American higher education. University of Virginia Press.

Brief of the American Educational Research Association et al., as Amici Curiae in Support of Respondents, Fisher v. University of Texas, 80 U.S.L.W. 3475 (2012) (No. 11 - 345).

Brown v. Board of Education, 347 U.S. 483 (1954). 
Journal Committed to Social Change on Race and Ethnicity | 2016

Council of Graduate Schools. (2008a). Graduate education and the public good. Washington, DC: Council of Graduate Schools

Council of Graduate Schools. (2008b). Ph.D. Completion Project. Retrieved from http://www.phdcompletion.org/information/index.asp

Council of Graduate Schools. (2009). Broadening participation in graduate education. Washington, DC: Council of Graduate Schools.

Cruz, D. (1995). Struggling with the labels that mark my ethnic identity. In R.V. Padilla \& R. C. Chavez, The leaning ivory tower: Latino professors in American Universities (pp. 91 - 100). Albany, NY: State University of New York Press.

Davidson, M., \& Foster-Johnson, L. (2001). Mentoring in the preparation of graduate researchers of color, Review of Educational Research, 71(4), 549 - 574.

Diangelo, R. (2006). The production of Whiteness in education: Asian international students in a college classroom. Teachers College Record, 108(10), $1983-$ 2000.

Felder, P. (2010). On doctoral student development: Exploring faculty mentoring in the shaping of African American doctoral student success, The Qualitative Report, 15(2), $455-474$.

Fisher v. University of Texas, 631 F.3d 213 ( $5^{\text {th }}$ Cir. 2011).

Fisher v. University of Texas, 645 F. Supp. 2d 587 (W. D. Tex. 2009).

Fisher v. University of Texas, 80 U.S.L.W. 3475 (2012).

Foucault, M. (1977). Discipline and punish: The birth of the prison. New York, NY: Random House, Inc.

Garces, L. M. (2012). Racial diversity, legitimacy, and the citizenry: The impact of affirmative action bans on graduate school enrollments. The Review of Higher Education, 36(1, supplement), 93 - 132.

Gardner, S. (2008). What's too much and what's too little: The process of becoming an independent researcher in doctoral education. The Journal of Higher Education, 79(3), $327-349$.

Gardner, S. (2009). The development of doctoral students: Phases of challenge and support. ASHE-Eric Higher Education Report, 34(6), 1 - 14. 
Journal Committed to Social Change on Race and Ethnicity | 2016

Gardner, S. K. \& Barnes, B. J. (2007). Graduate student involvement: Socialization for the professional role. Journal of College Student Development, 48, 369-387.

Gardner, S. \& Holley, K. (2011). "These invisible barriers are real": The progression of first-generation students through doctoral education. Equity \& Excellence in Education, 44(1), 77 - 92.

Gasman, M., Gerstl-Pepin, C., Aderson-Thompkins, S., Rasheed, L., \& Hathaway, K. (2004). Developing trust, negotiating power: Transgressing racer and status in the academy. Teachers College record, 106(4), $689-715$.

Gasman, M., Hirschfield, A., \& Vultaggio, J. (2008). "Difficult yet rewarding": The experiences of African American graduate students. Journal of Diversity in Higher Education, 1(2), 126 - 138.

Gay, G. (2004). Navigating marginality en route to the professoriate: graduate students of color learning and living in academia. International Journal of Qualitative Studies in Education, 17(2), 265 - 288.

Gildersleeve, R., Croom, N., \& Vasquez, P. (2010). “Am I going crazy?!": A critical race analysis of doctoral education. Equity \& Excellence in Education, 44(1), 93 - 114.

Girves, J. \& Wemmerus, V. (1988). Developing models of graduate student degree progress. The Journal of Higher Education, 59(2), 163 - 189.

Golde, C. M. (2005). The role of the department and discipline in doctoral student attrition: Lessons from four departments. Journal of Higher Education, 76, 669700.

Golde, C. \& Dore, T. (2001). At cross purposes: What the experiences of doctoral students reveal about doctoral education. Philadelphia: The few Charitable Trusts

Gonzales, J. (2006). Academic socialization experiences of Latina doctoral students: A qualitative understanding of support systems that aid and challenges that hinder the process. Journal of Hispanic Higher Education, 5(4), 347 - 365.

Gonzales, K., Marin, P., Figuerosa, M., Moreno, J., \& Navia, C. (2002). Inside doctoral education in America: Voice of Latinas/os in pursuit of the PhD. Journal of College Student development, 43, 540 - 557. 
Journal Committed to Social Change on Race and Ethnicity | 2016

Gopaul, B. (2011). Distinction in doctoral education: Using Bourdieu's tools to assess the socialization of doctoral students. Equity \& Excellence in Education, 44(1), 10 -21 .

Gratz v. Bollinger, 539 U.S. 244 (2003).

Grutter v. Bollinger, 539 U.S. 306 (2003).

Guba, E. G. \& Lincoln, Y. S. (1994). Competing paradigms in qualitative research. In, N. Denzin, \& Y. Lincoln (Eds.). Handbook of qualitative research, ( $1^{\text {st }} \mathrm{Ed}$.) (pp. 105 117). Thousand Oaks, CAL Sage Publications, Inc.

Gubrium, E. \& Koro-Ljungberg, M. (2005). Contending with border making in the social constructionist interview. Qualitative Inquiry, 11, 689 - 715.

Gubrium, J. F. \& Holstein, J. A. (1997). The new language of qualitative method. New York, NY: Oxford University Press, Inc.

Gubrium, J. F. \& Holstein, J. A. (2001). (Eds). Institutional Selves: Troubled identities in a postmodern world. New York, NY: Oxford University Press, Inc.

Gubrium, J. F. \& Holstein, J. A. (2003). (Eds.) Postmodern interviewing. Thousand Oaks, CA: Sage Publications, Inc.

Gubrium, J. F. \& Holstein, J. A. (2009). Analyzing narrative reality. Thousand Oaks, CA: Sage Publications, Inc.

Hall, L. \& Burns, L. (2000). Identity development and mentoring in doctoral education. Harvard Educational Review, 79(1), 49 - 70.

Harper, S. (2012). Race without racism: How higher education researchers minimize racist institutional norms. The Review of Higher Education, 36(1, supplement), 9 -30 .

Harper, S. \& Porter, A. (2012). Attracting Black male students to research careers in education: A report from the grad prep academy project. Philadelphia: University of Pennsylvania, Center for the Study of Race and Equity in Education.

Harvey, W. \& Anderson, E. (2005). Minorities in higher education: Twenty first annual status report 2003 - 2004. Washington, DC: American Council on Education.

Heller, D. (1997) Student price response in higher education: An update to Leslie and Brinkman. Journal of Higher Education, 68, 624 - 659. 
Journal Committed to Social Change on Race and Ethnicity | 2016

Hollins, E. (2011). The meaning of culture in learning to teach: The power of socialization and identity formation. In A. Ball \& C. Tyson (Eds.) Studying diversity in teacher education (pp. 105 - 130). Lanham, MD: The American Educational Research Association and Rowman \& Littlefield Publishers, Inc. Holstein, J. A. \& Gubrium, J. F. (1995). The active interview: Qualitative Research Methods, Volume 34. Thousand Oaks, CA: Sage Publications, Inc.

Holstein, J. A. \& Gubrium, J. F. (1998). Phenomenology, ethnomethodology, and interpretive practice. In N. Denzin \& Y. Lincoln (Eds.), Strategies of qualitative inquiry (pp. 137 - 157). Thousand Oaks: Sage Publications, Inc.

Holstein, J. A. \& Gubrium, J. F. (2000). The self we live by: Narrative identity in a postmodern world. New York, NY: Oxford University Press, Inc.

Hopwood v. Texas, 78 F.3d $932\left(5^{\text {th }}\right.$ Cir. 1996).

Hu, S., \& St. John, E. (2001). Student persistence in a public higher education system: Understanding racial and ethnic differences. The journal of higher education, 72(3), $265-286$.

Hurtado, S., Milem, J., Clayton-Pedersen, A., \& Allen, W. (1999). Enacting diverse learning environments: Improving the climate for racial/ethnic diversity in higher education. ASHE-ERIC Higher Education Report, Vol. 26, No. 8. Washington DC: ERIC Clearinghouse on Higher Education,

Hussar, W. J. \& Bailey, T. M. (2011). Projections of educational statistics to 2019 (NCES 2011-017). National Center for Education Statistics, Institute of Education Sciences, U.S. Department of Education, Washington, DC.

Johnson-Bailey, J., Valentine, T., Cervero, R., \& Bowles, T. (2009). Rooted in the soil:

The social experiences of Black1 graduate students at a Southern Research University. Journal of Higher Education, 80(2), 178 - 203.

Kuh, G. D. \& Whitt, E. J. (1988). The Invisible Tapestry. Culture in American Colleges and Universities. ASHE-ERIC Higher Education, Report No. 1, 1988. Washington DC: Association for the Study of Higher Education

Lajimodiere, D. (2012). A healing journey. Wicazo Sa Review, 27(2), 5 - 19.

Lawrence, A. (2009). Uncloaking epistemologies through methodology. In R. WinkleWagner, C. Hunter, \& D. Ortloff (Eds.) Bridging the gap between theory and 
Journal Committed to Social Change on Race and Ethnicity | 2016

practice in educational research: Methods at margins (pp. 79 - 84). New York, NY: Palgrave Macmillan.

Leslie, L. \& Brikman, P. (1988). The economic value of higher education: New York, NY: Macmillan.

Lomawaima, K. T. \& McCarty, T. L. (2006). "To remain an Indian”: Lessons in democracy from a century of Native American education. Teachers College Pr.

Lovitts, B. E. (2001). Leaving the ivory tower: The causes and consequences of departure from doctoral study. Lanham, MD: Rowman \& Littlefield.

Lovitts, B. E. (2005). Being a good course-taker is not enough: A theoretical perspective on the transition to independent research. Studies in Higher Education, 30, 137154.

Lovitts, B. E. (2008). The transition to independent research: Who makes it, who doesn't, and why. The Journal of Higher Education, 79(3), 296 - 325.

Lovitts, B. E., \& Nelson, C. (2000). The hidden crisis in graduate education: Attrition from Ph.D. Programs. Academe, 86 (6), 44-50.

Mayhew, M., Rochenbach, A., Bowman, N., Seifert, T., Wolniak, G., Pascarella, E., \& Terenzini, P. (2016). How college affects students, Volume 3: $21^{\text {st }}$ century evidence that higher education works. Hoboken, NJ: John Wiley \& Sons, Inc.

McDaniels, M. (2010). Doctoral student socialization for teaching roles. In P. Mendoza \& S. Gardner. (Eds.) On becoming a scholar: Socialization and development in doctoral education $(29$ - 44). Sterling: Stylus Publishing, LLC.

McDermott, R., \& Varenne, H. (1995). Culture as disability. Anthropology and Education Quarterly, 26(3), 324 - 348.

McLaurin v. Oklahoma State Regents, 339 U.S. 647 (1950).

Mendez, et al v. Wesminster School District of Orange County, et al, 161 F.2nd 774 (1947).

Mendoza, P. (2007). Academic capitalism and doctoral student socialization: A case study. The Journal of Higher Education, 78(1), 71 - 96.

Mendoza, P. \& Gardner, S. (2010). On becoming a scholar: Socialization and development in doctoral education (Eds.). Sterling: Stylus Publishing, LLC. 
Journal Committed to Social Change on Race and Ethnicity | 2016

Miller, L. (2008). Foucaldian constructionism. In J. A. Holstein \& J. F. Gubrium (Eds), Handbook of constructionist research, (pp. 251 - 274). New York: The Guilford Press.

Mills, C. W. (1959). The sociological imagination. New York: Oxford University Press.

Museus, S., Palmer, R., Davis, R., \& Maramba, D. (2011). Racial and ethnic minority student success in STEM education: ASHE higher education report. Hoboken, NJ: John Willey \& Sons, Inc.

National Science Foundation (1998). Summary of Workshop on Graduate Student Attrition [NSF 99-314] Arlington, VA: National Science Foundation, Division of Science Resources Studies.

Newman, F., Couturier, L., \& Scurry, J. (2004). The future of higher education: Rhetoric, reality, and the risks of the market. San Francisco: Jossey - Bass.

Noori, M. (2011). Waasechibiiwaabikoonsing Nd'anami'aami, "Praying through a Wired Window": Using Technology to Teach Anishinaabemowin. Studies in American Indian Literatures, 23(2), 1-23.

Nyquist, J., Manning, L., Wulff, D., Austin, A., Sprague, J., Fraser, P., Calcagno, C., \& Woodford, B. (1999). On the road to becoming a professor: The graduate student experience. Change, $18-27$.

Olivas, M. (2006). The law and higher education: Cases and materials on colleges in court. Durham, NC: Carolina Academic Press.

O'Neal Green, D. \& Trent, W. (2005). The public good and a racially diverse democracy. In A. Kezar, T. Chambers, \& J. Burkhardt (Eds.), Higher education for the public good: Emerging voices from a national movement, (pp. 102 - 124). San Francisco, CA: Jossey-Bass.

Oyserman, D. \& Sakamoto, I. (1997). Being Asian American: Identity, cultural constructs, and stereotype perception. Journal of Applied Behavioral Science, 33(4), 435-453.

Parents Involved in Cmty. Schs, v. Seattle Sch. Dist. No 1, 551 U.S. 701 (2007).

Patton, S. (2013). ETS shares data on first crop of students who took revised GRE test. Retrieved from http://chronicle.com/article/ETS-Shares-Data-on-FirstCrop $/ 137435 /$ ?cid=gs\&utm_source=gs\&utm_medium=en. 
Journal Committed to Social Change on Race and Ethnicity | 2016

Patton, L. (2009). My sister's keeper: A qualitative examination of mentoring experiences among African American women in graduate and professional schools. The Journal of Higher Education, 80(5), 510 - 537.

Paulsen, M. \& St. John, E. (2002). Social class and college costs: Examining the financial nexus between college choice and persistence. The journal of Higher Education, 73(2), 189 - 236.

Pryor, J. H., Hurtado, S., Saenz, V. B., Santos, J. L., \& Korn, W. S. (2007). The American freshman: Forty year trends. Los Angeles: Higher Education Research Institute.

Rendon, L., Jalomo, R., \& Nora, A. (2000). Theoretical consideration in the study of minority student retention in higher education. In J. Braxton (Ed.) Reworking the student departure puzzle ( $1^{\text {st }} \mathrm{Ed}$.). (pp. 127 - 156). Vanderbilt University Press

Regents of the Univ. of Cal. V. Bakke, 438 U.S. 265 (1978).

Sallee, M. (2011). Performing masculinity: Considering gender in doctoral student socialization. The Journal of Higher Education, 82(2), 187 - 216.

Scheurich, J. (1995). A postmodernist critique of research interviewing. Qualitative Studies in Education, 8(3), 239 - 252.

Shutz, A. (1967). The phenomenology of the social world. Evanston, IL: Northwestern University Press.

Sipuel v. Board of Regents, 332 U.S. 631 (1948).

Snyder, T., \& Dillow, S. (2011). Digest of education statistics 2010. (NCES 2011-015). National Center for Education Statistics, Institute of Education Sciences, U.S. Department of Education, Washington, DC.

Sowell, R., Bell, N., \& Kirby, S. (2010). Ph.D. completion and attrition: Policies and practices to promote student success. Washington, CD: Council of Graduate Schools.

Stage, F. (2007). Answering critical questions using quantitative data. New Directions for Institutional Research, 133, 5 - 16.

Stewart, D-L. (2013). Racially minoritized students at U.S. four-year institutions. The Journal of Negro Education, 82(2), 184 - 197. 
Journal Committed to Social Change on Race and Ethnicity | 2016

St. John, E. (2002). The access challenge: Rethinking the causes of the new inequality [Policy Issue Report 2002 - 01]. Bloomington, IN: Indiana Education Policy Center.

St. John, E. (2006a). Contending with financial inequality: Rethinking the contributions of qualitative research to the policy discourse on college access. American Behavioral Scientist, 49(12), 1604 - 1619.

St.John, E. (2006b). Education and the public interest: School reform, public finance, and access to higher education. Dordrecht, The Netherlands: Springer.

St.John, E., Daun-Barnett, N., \& Moronski-Chapman, K. (2013). Public policy and higher education: Reframing strategies for preparation, access, and college success. New York, NY: Taylor \& Francis.

St. John, E. \& Musoba, G. (2011). Pathways to academic success: Expanding opportunity for underrepresented students. New York: Routledge.

St. John, E. \& Noell, J. (1989). The impact of financial aid on access: An analysis of progress with special consideration of minority access. Research in Higher Education, 30(6), 563 - 582.

St. John, E., Paulsen, M., \& Carter, D. (2005). Diversity, college costs, and postsecondary opportunity: An examination of the financial nexus between college choice and persistence for African Americans and Whites. The Journal of Higher Education, 76(5), 545 - 569.

Tierney, W. (2008). The impact of culture on organizational decision making: Theory and practice in higher education. Sterling, VI: Stylus Publishing, LLC.

Tierney, W. \& Rhoads, R. (1993). Postmodernism and critical theory in higher education: Implications for research and practice. Higher education handbook of theory and research. $308-343$.

Tinto, V. (1993). Leaving college: Rethinking the causes and cures of student attrition (2d ed.) Chicago, IL: University of Chicago Press.

United States v. Fordice, 505 U.S. 717 (1992).

U.S. Census Bureau. (2012). 2012 national population projections. Retrieved from http://www.census.gov/population/projections/data/national/2012.html 
Walker, G., Golde, C., Jones, L., Bueschel, A., \& Hutchings, P. (2008). The formation of scholars: Rethinking doctoral education for the twenty-first century. San Francisco: Jossey - Bass.

Weidman, J. C., Twale, D. J., \& Stein, E. L. (2001). Socialization of graduate and professional students in higher education: A perilous passage? San Francisco: Jossey-Bass.

Weidman, J. \& Stein, E. (2003). Socialization of doctoral students to academic norms. Research in Higher Education, 44(6), 641 - 656.

Winkle-Wagner, R., Ortloff, D., \& Hunter, C. (2009). The not-center?: The margins and educational research. In R. Winkle-Wagner, C. Hunter, \& D. Ortloff (Eds.), Bridging the gap between theory and practice in educational research: Methods at margins (pp. 1 -14). New York, NY: Palgrave Macmillan.

Zusman, A. (2005). Challenges facing higher education in the twenty-first century. In Altbach, P., Berdahl, R., \& Gumport, P. (Eds.), American higher education in the twenty-first century: Social, political, and economic challenges (pp. 115 - 162) $\left(2^{\text {nd }}\right.$ ed. $)$. Baltimore: The John Hopkins University Press. 